\title{
The Process of Dissimilation in English and Arabic: A Comparative Study
}

\author{
Aseel Muhammad Faiq \\ Dept. of English, School of Languages \\ University of Sulaimani, Sulaimani, Iraq \\ asilmf@yahoo.com
}

\author{
Israa Burhanuddin \\ Dept. of English, College of Education for Women \\ University of Tikrit, Salahddin, Iraq \\ say_awab@yahoo.com
}

\begin{abstract}
Unlike the process of assimilation, which is a phonological process in which two sounds that are different become more alike, dissimilation is a process in which sounds that are alike become different. The present paper is concerned with showing dissimilation process in both English and Arabic languages. It seeks to investigate the main causes behind this process beside its main classifications and whether these causes and classifications are found in the two languages under study. The comparative analysis findings show that both languages share similar incentives and classifications and this, in turn, renders the process as being universal, sporadic and quantal (non-gradual). Moreover, it has been found that dissimilation is not only achieved by differentiating sounds, other processes may help to dissimilate elements and to make sounds more dissimilar and distinct.
\end{abstract}

Keywords: Dissimilation, Assimilation, Sound Change, Different, Ease of articulation

\section{INTRODUCTION}

Sounds can be modified based on the sounds surrounding them by anticipating the sounds after them or being influenced by the sounds before them and the result will be a sound change where either sounds become similar or different from their neighboring sounds. The process by which sounds become similar or identical to the surrounding sounds is called assimilation. Clear examples are found in the plural suffix $/ \mathrm{s} /$. This sound is pronounced as actual $/ \mathrm{s} /$ after voiceless sounds as in cats /kats/, and it is pronounced as /z/ after voiced sounds as in $\operatorname{dog}_{s} / \mathrm{dog} z /$. Other examples may include a phrase like 'right place' which can be pronounced as /raip pleis/ in which the alveolar/t/ is changed into a bilabial /p/, i.e. they become similar in their places of articulation. Phrases like 'good night' /gud nait/, 'have to' /hæv tu/, and 'sit down' /sit daun/ may also undergo assimilation to be produced as /gun nait/ where the plosive /d/ is altered into a nasal /n/, /hæf tu/ where /v/loses its voice, and /sid daun/ where /t/ copies voice from the following /d/. The easiest explanation for this is that: "one consequence of putting phonemes together in close proximity is that they sometimes become more like each other than they would be in isolation" (Jeffries, 2006:53). Thus, it is the influence of the neighboring sounds that is the determinant of the type of variety to be chosen. When this influence causes sounds to be more different (rather than similar) from each other, the process of dissimilation takes place. Dissimilation is the opposite process of assimilation. It refers to the influence exercised by one sound segment upon the articulation of another, so that the sound becomes less similar or different from other neighboring sounds (Crystal, 2008:177).

Different views have been proposed to look at both assimilation and dissimilation processes. Lawrence (1973:7) assumes that both processes are not opposite to each other in that each is motivated by different principles. Assimilation is mainly motivated phonetically (allowing articulatory ease), while dissimilation is explained within the phonological domain (preserving grammatical distinctions). This clarifies that although the effects of both processes are in a sense opposite, their domains of application are not comparable. Therefore, the two processes are not isomorphic opposites (ibid:6). Assimilation is also considered as a widespread, general and natural process while dissimilation is seen as restricted, uncommon and unnatural one, hence, a marginal source of sound change (Strazny, 2005:97). Another view sees both processes as two sides of the same coin. Hickey (1984: 279) proposes that the principles governing assimilation also govern dissimilation, or at least their converse do. He finds that many changes in the phonological structure 
in Old English are in fact both assimilation and dissimilation in combination. For example the shift $/ 1 \theta /$ to $/ \mathrm{ld} /$ is assimilation in terms of place of articulation and voice and dissimilation in terms of the continuancy of both segments (ibid). In general, then, the two processes are aspects of connected speech and both can be explained as constraints pertaining to the co-occurrence of some salient feature within some defined boundary, codifying a preference in the language for certain segmental features either to be similar or to disagree(Collier,2013:4). The current paper deals with dissimilation as a phonological process in both English and Arabic languages. It tries to show what similar and/or different points may be found in the two languages as far as dissimilation causes and classification. It seeks to investigate what features are typically involved and what types of conditions may be placed on dissimilation rules so as to see whether dissimilation is regular or sporadic, gradual or quantal within the two languages under study.

\section{Causes of Dissimilation}

As has been mentioned above, dissimilation is a phenomenon where two sounds in a given word or phrase become less similar to each other. This process happens due to a variety of reasons, some of which are ascribed to language borrowing when a word makes its way from one language to another. For example, when French words are used in English, they may undergo dissimilation as when the word marble, take on an /1/ sound, while its original French word was marbre. Latin words are famous in undergoing this process when they come to be used in English (Denham and Lobeck, 2010:80) (see 4.4).

Other causes look at the speaker and/or the listener as their point of departure. Malamberg (1984: 6465 ) states that the production of identical adjacent sounds requires a more nervous concentration and a larger muscular effort than needed or than necessary in the production of dissimilar adjacent sounds. This means that similarity avoidance effects are due to the difficulties associated with processing the sequencing of similar segments. The speaker resorts to substitute, sometimes unconsciously, one of these identical sounds with another to avoid this difficulty. In other words, the speaker tends to lessen the muscular and nervous efforts required in producing sounds. Another view that takes the speaker as its main reason for dissimilating similar sequences is that of Bergstrasser (1994: 34). This orientalist hypothesizes that dissimilation is due to a purely psycholinguistic reason similar to that responsible for tongue slips. He explicates that a speaker occasionally commits pronunciation mistakes and sometimes utters a sound that $\mathrm{s} / \mathrm{he}$ hasn't planned to utter especially when uttering two successive identical sounds. Bergstrasser further comments that each speaker has an inner working highly complex system and has a mental image for each sound and a perception of the necessary movements needed to utter a sound. Therefore, it would be difficult for the speaker to re-conceptualize the same movements needed for the identical sound shortly after the already uttered one. Bergstrasser (ibid: 35) goes beyond the speakers' efforts in producing utterances and cares about their perception by the listener. He finds that there is a perceptual motivation for dissimilation which needs to increase the auditory/perceptual contrast among sounds in a sequence (syntagmatic contrast). The Greek change: $\mathrm{pt} \rightarrow \mathrm{ft}, \quad \mathrm{f} \theta \rightarrow \mathrm{ft}$ is doubly perceptual in nature as it both dissimilates continuancy, as well as enhances place cues by having the consonant at the CV (Consonant- Vowel) boundary be a stop (stop place cues are stronger in $\mathrm{CV}$ position than in $\mathrm{CC}$ or $\mathrm{VC}$ position). Another reason within the perceptual domain that takes the effect on the listener as its point of departure is the one that finds the speaker as being not content with only stressing a sound or geminate it to gain the required effect. Rather, the speaker sometimes resorts to change one of two or three successive identical sounds (geminates) or sometimes add one or two sounds to gain a certain effect on the listener. Fletch (1983: 156) assures, too, that dissimilation in many cases doesn't arise to mend some pronunciation difficulty; rather it is used for the sake of exaggeration or other pragmatic reasons. In other words, the speaker sometimes uses dissimilation intentionally as a way to make certain words stand out in the language and to be more expressive. According to this factor, dissimilation is part of an artistic or poetic process dealing with the repetition or there duplication of vowel or consonant sounds. In considering rhyme in English, one is not only concerned with counting features, contrastive segments seem more interesting and supportive. A clear example may be found in English shm- reduplication in which potatoshmotato, seems more plausible than shmaltz-shpaltz due to the constraint against the repetition of identical elements as well as the non-identity echo requirement (Yip, 1995:67). Ar-Rāzī (1993: 101-2) supports a good example illustrating this issue of varying the style to conjure good public

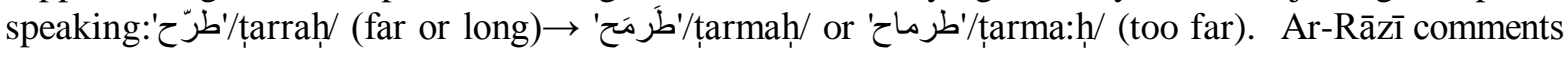


that the sound $/ \mathrm{m} /$ or $/ \mathrm{ma} /$ are used for the sake of giving the word the exaggerated meaning of 'terribly long distance'. He further states that the addition of these sounds 'distorts or changes' the echo of the word leading the listener to receive the intended implication (ibid).

Other theories on dissimilation causes resort to the listener as John Ohala's (1981) theory. Ohala proposes that dissimilation originates as mistakes on the part of the listener. These mistakes stem from the fact that the acoustic effects of certain phonological features tend to spread across adjacent sounds. For example, a consonant's place of articulation affects the formant transitions on neighboring vowels and consonants, and vowels affect vowels in neighboring syllables, even over intervening consonants (Öhman 1966 Cited in Hall,2009:20). This coarticulation poses a problem for the listener. In order to correctly identify the intended utterance, the listener must learn to factor out coarticulation. This factoring out either fails so that the listener takes an automatic coarticulatory effect as phonologically real, or it happens so that the listener may overcorrect by attributing a phonologically intended phonetic detail to context. The former case has been referred to as hypo-correction as the listener constructs an underlying representation in which the two phonemes agree on the coarticulated feature. The latter case is hypercorrection which is a kind of mental inversion of a perceived phonetic coarticulation. The listener constructs an underlying representation in which a feature that should be assigned to two phonemes is assigned only to one (Ohala 1981, 1992, 1993).It is hypercorrection that Ohala hypothesized to be responsible for the phonological phenomenon of dissimilation. Listeners hearing two identical sounds within a phonological domain may misattribute the perceived occurrence of one sound to the resonance effects of the other, and begin to adjust their mental representations of the underlying sounds, possibly leading to an eventual dissimilation rule in the language. For example, hearing a word with two aspirates in proximity, the listener may interpret the aspiration on one as an automatic effect of the other, and may then suppress it when speaking (Ohala,1993:251).This is mainly Grassmann's law which states that: when a word has two aspirations, the first of the two aspirated stops is to be dissimilated so that the first loses its aspiration. This type of dissimilation is especially applied in Old Greek and Sanskrit and hints at dissimilation as a regular natural process. Another example supplied by Hall (2009:2) in support of Ohala's hypercorrection is when she argues that $/ \mathrm{r} /$ sound, mainly in the pronunciation of rhotic speakers, tends to disappear where it should be most phonetically masked by the presence of a second /r/ as in /səpraiz/ for surprise, /pətikjələ/ for particular, /g $\Lambda$ vənə/ for governor, and so on (see below/ section 6).

Consequently, most of the cases of dissimilation are made as a way to facilitate speech and/or to make it more distinct and different.

\section{DisSimilation IN THE TWO LANGUAGES UNDER STUDY}

As long as English has been a language it has been changing. Both throughout the course of Old English and in the transition from Old to Middle to Modern English, a large number of changes especially in the phonological structure of words had far reaching consequences for the development of English. This is because language is always evolving to be more efficient and smooth through new techniques and more easier processes (Hickey,1984:279). Dissimilation describes a situation in which one sound has become less like another in its vicinity. However, not all sequences of similar sounds are as liable to dissimilation as others, Liquids $/ 1, \mathrm{r} /$, nasals $/ \mathrm{n}, \mathrm{m}, \mathrm{y} /$, and segments that demand complex readjustments in the glottis, such as aspirated, murmured, and glottalized stops, seem particularly prone to dissimilation (ibid).

In Arabic language, dissimilation seems to have similar incentives and effects to that of the English language. Arab scholars maintain that it is when sounds geminate together, they become liable to dissimilation. The geminated sequence of sounds are to be differentiated or an embedded sound is to be added to the sequence so as to achieve the goal of releasing the difficulty. Fletch (1983:156) mentions that dissimilation in Arabic arises when one of the labials /b, m, f/; or the dentals /d, t, t, d,, , $\oint, \theta, \mathrm{z}, \mathrm{s}, \mathrm{s} /$; or the velar /k/; or the affricate /dz/ are geminated. Whereas Anīs (1995: 213) states that dissimilation arises when occlusive sounds (ițbāq /rițāq/ sounds) /ș, d, ț, ợ/ are geminated because they need more muscular effort than any other sounds. On the other hand, Brokelman (1977: 74-75) seems to include larger groups of sounds. He states that dissimilation triggers when the liquids $/ \mathrm{r}, 1 /$; or the labials $/ \mathrm{b}, \mathrm{f}, \mathrm{m} /$; or the hissing sounds $/ \mathrm{s}, \mathrm{s}, \mathrm{z}, \mathrm{J} /$; or the dentals $/ \mathrm{d}, \mathrm{t}, \mathrm{t}, \mathrm{d}, \mathrm{d}$, $\mathrm{j}_{1}$; or the glottals /2, $\mathrm{h}, \mathrm{h}, \mathrm{G} /$; or $/ \mathrm{k}$, dz/ come to be geminated.). According to the statics made by Bahra (2010), it can be surprisingly observed that all Arabic consonants when geminated or occur in close proximity, are prone to dissimilation, though in varying proportions. So, it is certain sequences that are more liable to 
dissimilation than others as is the case of liquid dissimilation which proves to be common in most of the world's languages.

\section{TYPES OF DisSIMILATION}

Like assimilation, dissimilation can occur both within words (adjacent) or across word boundaries (non-adjacent), with sounds affecting each other either regressively or progressively. Other parameters for dissimilation classification may include whether dissimilation is a change that affects manner or place of articulation as well as whether it is diachronic or synchronic (Strazny,2005:97). According to such parameters dissimilation can be classified to the following types:

\subsection{Regressive vs. Progressive Dissimilation}

This classification concerns the directionality of change. Regressive or 'anticipatory' dissimilation refers to the effect of a later sound on a preceding one. It is a right-to-left change. It is more common than when dissimilation occurs in the opposite direction (i.e, progressive). Regressive dissimilation may occur as in the English word amphitheater which is very commonly pronounced ampitheater in which the first $/ \mathrm{h} /$ is deleted as a way to dissimilate the /f/ sound with the $/ \theta /$ so that instead of pronouncing the word as /æmfi is, instead of two sequential fricatives of $/ \mathrm{f} / \ldots / \theta /$, one is left with a plosive $/ \mathrm{p} /+$ a fricative $/ \theta /$. The effect here is regressive as it is the $/ \theta /$ sound that affects the preceding /f/ sound. It is a backward dissimilation. Unlike English, the direction of dissimilation in Arabic can be guessed depending on the root of the word, triple or quad rooted, and on proximity (Al-Kisā̄î, 1982: 116).Tri-root words (words with three sounds) that have their second sound geminated show regressive dissimilation by changing the first geminated sound to $/ \mathrm{r} /$ and keeping the other sound so that germination is released as in:

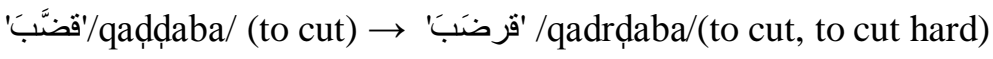

'سبّد'/sabbada/ (to have his hair cut) $\rightarrow$ 'سبرد' /sabrada/ (to have his hair cut) (Abduttawwāb, 1989: 58)

Regressive dissimilation at a distance may also be found in English as in the word eksetera /eksetora/ for etcetera /etsetəra/ which shows the influence of the second / $t$ / over the first / $t$ / by changing it to $/ \mathrm{k} /$. Moreover, the common misspelling ect. of the abbreviated form of the word implies dissimilation. In Arabic, the Quad-root words (words with four sounds) having the sounds in question to be nonadjacent, show regressive dissimilation in which the first sound is to be changed due to the effect of the coming one as in:

'ضمضر'/d̦arḍam/ (lion, or brave like a lion) (Ibid.)

Progressive dissimilation, also called lag dissimilation, refers to the effect of an earlier sound on a later one. It is a forward effect, i.e. a left-to-right change. It can be found in English as in the word chimney which may be dissimilated as chimley (see below). Instances of multiple occurrences of $/ \mathrm{r} /$ sound within a word are often sporadically dissimilated so that the first $/ r /$ may appear as $/ 1 /$ as in the English word 'pilgrim' which is from the Latin word 'peregrinus'. This means that the word was originally having two /r/s, however, when it came to English, the first /r/ is changed to $/ 1 /$ under the influence of the second /r/.This is a distant progressive dissimilation (Campbell, 1998:49).

In Arabic quad-root words may show progressive dissimilation within adjacent sounds as in ,

'خُرنّوب'xurnu:b/ (a tree)

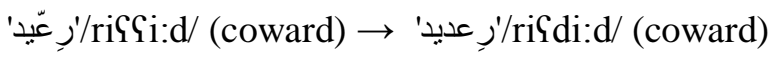

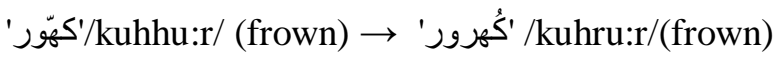

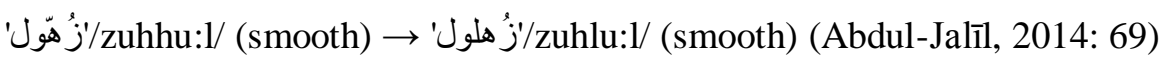

Other quad-root words derived from tri-root words with germination show a different case of dissimilation in which it is difficult to guess the direction of which. In this case three successive identical sounds are confronted the second of which shows dissimilation, e.g.

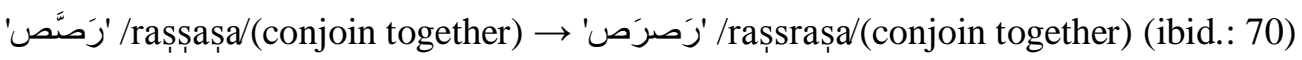


Dissimilation in this respect plays significant role in modifying the moods of some words in Arabic which results in enlarging the Arabic lexicon.

\subsection{Adjacent vs. Non-adjacent Dissimilation}

This classification concerns itself with sound distance, that is, whether the sounds are adjacent (contiguous) to each other or non-adjacent (non-contiguous). Adjacent dissimilation (also called local dissimilation) means that there is no distance between the two sounds in question. Non-adjacent dissimilation (also called distant dissimilation) occurs where one sound affects another even though other segments intervene. In English, adjacent dissimilation can be found in the non-standard pronunciation chimley $/ \mathrm{t} \mathrm{jimli} /$ for the standard chimney $/ \mathrm{t} / \mathrm{imni} /$. Such a dialectal use shows that $/ \mathrm{m} /$ and $/ \mathrm{n} /$ are both nasals and hence more difficult to pronounce than if a lateral /l/ is used instead. Another process maybe also involved in which an epenthetic /b/ is added so the resultant will be something like: chim(b)ley /t $\mathrm{fimbli} /$. Other examples are the words diphthong /dif $\theta \mathrm{oy} /$, diphtheria /dif $\underline{\theta}$ iəriə/ which have two fricatives /f/ $/ \theta /$ adjacent to each other. Speakers sometimes dissimilate such a sequence making it a plosive $/ \mathrm{p} /+$ a fricative $/ \theta /$ so the resultant will be something like:dipthong

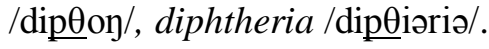

In Arabic, adjacent dissimilation occurs in two shapes: it might occur in the shape of two adjacent identical sounds (geminated) one of which is changed, progressively or regressively, e.g.

'دنّار'/danna:r/ (a person who deals with coin) $\rightarrow$ 'دينار'/di:na:r/ (coin)

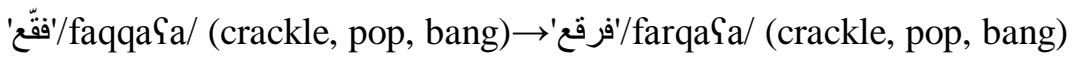

The other shape of adjacent dissimilation has the form of three identical consonants in which the second is affected, e.g.

'تملّك /tamallala/ (overturn and overturn in his bed) $\rightarrow$ 'تململ' /tamalmala/ (overturn and overturn in his bed)

Dissimilation may also occur between non- contiguous (non-adjacent) sounds as some other sounds will intervene between the sounds in question as in the English words velar/vi:la/ (also alveolar, and uvular) which was originally taken from the Latin velal. So the second /1/, which has a vowel sound separating it from the first /l/ , has changed to $/ \mathrm{r} /$ so as to sound smoother and more easier to be heard and perceived. In Arabic, non-contiguous dissimilation has the form of two identical sounds separated by a different sound. It shows progressive dissimilation, e.g.

هذه'/ha:ðih/ (demonstrative feminine pronoun) $\rightarrow$ 'هذي' هَ/ha:ð̄/ (demonstrative feminine pronoun)

The other form of distant dissimilation is the same as the case above except that the second sound is not changed, rather another sound is added to lessen the effort exerted in the pronunciation of such examples, e.g.

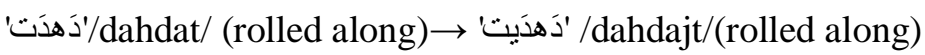

However, this case is sometimes categorized under insertion (Abdul-Jalīl, 2014: 73).

\subsection{Manner vs. Place Dissimilation}

This classification involves the degree to which the two sounds in question are similar to each other in place and in manner of articulation. Manner dissimilation refers to changing the segments in terms of manner. One clear cross-linguistic observation states that a stop + stop consonant cluster before a vowel is less common cross-linguistically than a fricative + stop or a stop + fricative before a vowel . The same applies for postvocalic stop clusters as well and clusters with two fricatives or two nasals. Examples clarifying this point can be found in the examples (above) of changing two fricatives to stop+ fricative as in diphthong to dipthong, two nasals to nasal + lateral as in the example chimney to chimley and so on (Hickey, 1984:281).

Place dissimilation occurs when the two segments are homorganic so that the sequence is disallowed. One general restriction of place, that is more common than others, is the one that prohibits a double occurrence of labials or any two homorganic consonants. Another restriction states that labials and dentals should not occur before velars. In English, one may have $/ \mathrm{kn} /, / \mathrm{pl} /, / \mathrm{kl} /$ sequences in Old 
English but not /t l/ which are both alveolar. There is however a plausible phonetic explanation for this: if a sonorant is preceded by a homorganic stop the latter cannot be perceived unless there is oral release with the sonorant following immediately (ibid:282).

In Arabic, dissimilation happens when one of the adjacent identical sounds is dissimilated into another so that the resultant sound maintains different manner of articulation from its adjacent sounds. It is found that, after dissimilation takes place, in most cases the substitute is of a totally different place of articulation in a way that the two adjacent sounds have distant places of articulation leading to lessen the effort while speaking. For example:

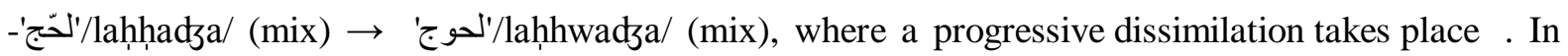
this example, the adjacent glottal, fricatives $/ \mathrm{hh} / \mathrm{are}$ dissimilated into /hw/ where /w/ is a bilabial glide.

-'بقّط'/baqqața/ (separate) $\rightarrow$ 'برقط'/barqața/ (separate), where a regressive dissimilation is triggered. Here, the velar, stops /qq/ are dissimilated into /rq/ where /r/ is an alveolar, trill.

\subsection{Diachronic vs. Synchronic Dissimilation}

Diachronic or historical dissimilation occurs when the word undergoes certain modifications throughout history, that is, the changes within the word have manifested themselves over a long period of time. Tracing the word purple, one can find that it is used in medieval English as purpul and purpure (in medieval French porpre) and comes from classical Latin purpura with dissimilation of /r/ to /1/. Other examples are the words 'pilgrim' from Latin 'peregrines', with the first / $\mathrm{r} /$ dissimilating to $/ 1 /$ and the word marble which is ultimately from the Old French marbre and further back from the Latin word marmor. Other more common examples are the Latin words in which a derivational suffix-al is attached to some Latin nouns to form adjectives. When the suffix is added to a noun that contained the liquid $/ 1 /$, the suffix is to be changed to -ar (rather than -al); that is, the liquid $/ 1 /$ is changed to the dissimilar liquid /r/. These words came into English as adjectives ending in -al or in its dissimilated form -ar. In other words, they become modern English -al and -ar. Thus words like: 'orbit, person, culture, electric' form their adjectives by adding the -al suffix as 'orbital, personal, cultural, electrical' respectively. However, words that have an /// preceding the ending anywhere in the root will be suffixed with -ar suffix as in 'single, module, luna' becoming 'singular, modular, lunar' respectively (Denham and Lobeck,2010:80). Other more examples can be seen in words like 'anecdotal, annual, mental, penal, spiritual, venal' adding the -al suffix while words like 'angular, annular, columnar, perpendicular, similar, velar' take the dissimilated -ar suffix due to the existing /// liquid in the root of the words. This rule applied actively in Latin, but doesn't in English. English merely inherited the dissimilated words (ibid).

In Arabic, diachronic dissimilation is observed in all the Arabic examples introduced above. However, the most heavily handled example in linguistic books is the one found in the word 'شمس'/Sams/ (sun). This word is traced in the Semitic Language of Arabic as 'نمش'/Jamf/ as in Hebrew and Aramaic (which belong to the same mother). The sound $/ \mathrm{g} /$ is substituted by $/ \mathrm{s} /$ in Arabic for some words, including 'شمش'/Jamf/, and this results in the word 'سمس'/sams/. Distant dissimilation between the two /s/s results finally in the word 'شمس' / 'شمams/ (Abduttawab,1989: 37). Another example of diachronic dissimilation is found in the plurals 'وواصل'w/wawa:sil/ (connectors) and 'واق'/wa:q/ (protectives). Regressive dissimilation takes place in these two words when the first $/ \mathrm{w} /$ of these words is substituted by the glottal stop /2/ resulting in 'أو اقو' 'أو /2awa:sawa:q/, respectively. The same can be said for 'اولى'/rawla:/ (ولى/rawal/ (the first-feminine)andmasculine)which are traced as 'وولى' 'ولى'/wawwal/, respectively (Ibin Jinnī, 2010: 90).

Synchronic dissimilation is also found in English. Clear examples are found in the tongue twisters which contain repeated similar onset consonants (e.g. sit zap zoo sip). Pronouncing such sounds is more difficult to produce than those that do not contain repeated onsets (e.g. sit shop zoo tip). Tongue twisters containing repetition are analogous to polysyllabic words containing pairs of similar segments, i.e., the input to dissimilation rules. Thus, there may be an additional functional motivation for dissimilation in the difficulty in processing words containing repeated segments during speech production (Berg 1998:36). Other examples of easing pronunciation through dissimilation may be found in some varieties of English, where there is a fricative dissimilation rule. This rule applies to sequences $/ \mathrm{f}+\theta /$ and $/ \mathrm{s}+\theta /$, changing them to $[\mathrm{f}+\mathrm{t}]$ and $[\mathrm{s}+\mathrm{t}]$. Here the fricative $/ \theta /$ becomes dissimilar 
to the preceding fricative by becoming a stop. For example, the words fifth /fif $\theta /$ and $\operatorname{sixth} / \mathrm{siks} \theta /$ come to be pronounced as if they were spelled fift /fift/and sikst /sikst/ (Frisch,2004:347).

In Arabic, just like in English, synchronic dissimilation is less common. However, dissimilation can be observed in some varieties of Arabic. 'زر 'زر /zarra/ (to fasten), for example, is sometimes dissimilated

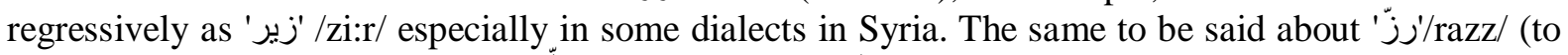

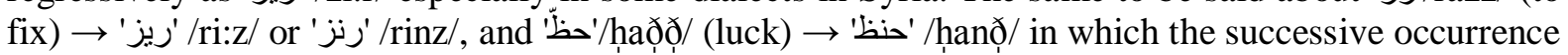
of three fricatives is broken by the substitution of the second fricative with an alveolar sound (Ibin Mandhur: 1988:425).

\section{Dissimilation of Vowels}

Dissimilation may also happen within vowel sounds. Vowel sounds in languages are often known to change over time. This can happen due to the emergence of different dialects or simply to trends in common usage. Some researchers have pinpointed specific types of dissimilation changes within a language. The commonest cases are those of delabialization and diphthongization. The former can be seen when a syllabic of /uu / is to be delabialized to /iu/, also that of /ou/can be delabialized to /ou/, this is mainly happening as delabialization is especially applicable to lower vowels. Diphthongization and diphthongal dissimilation occur most often in long or stressed syllables, especially in slow or emphatic speech; e.g: a word like no!, usually /nou/ or /nəu /could become /nau/ (by lowering) or /ncu/ (by palatalization) or even /nau/ (by both) under extreme emphasis (Donegan,2001:21). What is worth noting here is that the opposite process may also be found in that monophthongal vowels may be diphthongized. Examples of monophthongization like /ei / to /e/ or /ou/ to /u/ or /e:/ to /ei/or /ع:/ to /عə/ may all be analyzed as a dissimilatory enhancement of differences (ibid: 23)

Arabic vowels have a great share in dissimilation, especially that of the progressive, diachronic nonadjacent type. This is observed in the inflections of certain syntactic cases, as the following examples declare:

'يكتبانَ' /jaktuba:na/ (they write) $\rightarrow$ 'يكتبانِ /jaktuba:ni/ (they write), where the final /a/ is dissimilated to /i/ in dual verbs in nominative and accusative cases in order to avoid the repetition of the two vowels $/ \mathrm{a} / \mathrm{and} / \mathrm{a} /$ which are of the same quality.

'يكتبونُ' (they write) /jaktubu:nu/ $\rightarrow$ 'يكتبونَ' (they write) /jaktubu:na/, where the final /u/ is dissimilated into /a/ in masculine plural verbs in nominative case (Abduttawāb, 1989:43).

'بناتَ' 'بنات' > 'بن /bana:ti/ (girls). Plural nouns in accusative case are inflected with /a/, however this is not the case with feminine plurals: they are inflected with /i/ instead to release the difficulty of repeating the long vowel of the same quality that precedes them. Dissimilation of vowels in Arabic is often described as quantitative dissimilation since it deals with the quantity of the sound rather than its quality (Zedān, 1982: 62-63).

\section{Dissimillation Within Other Processes}

What is apparent in dissimilation process is the fact that it can be achieved not only by differentiating sounds, which is mainly referred to as preventive dissimilation, but also through other processes. One of the commonest processes is that of metathesis in which sounds exchange places with each other so that the $\mathrm{a} \rightarrow \mathrm{b}$ order may reverse to $\mathrm{b} \rightarrow \mathrm{a}$ one. Examples like: axe $\sim$ asce 'ashes', waxan $\sim$ wascan 'wash' assume that the $s c$ clusters originally represented ks then the $\mathrm{x}$ grapheme mus thave stood for the metathesized sequence of these consonants (Campbell, 2004: 170). However, the latter development of words with [xs] such as wahsan for wax /wæks/ shows that the double fricative sequence $\mathrm{h}+\mathrm{s}$ was resolved to a stop and fricative sequence $\mathrm{k}+\mathrm{s}$ so this type of sound change does not only undergo transposing (h- $\mathrm{s}$ ) sounds but also changing it to (k-s) ones. Other examples are those $/ \mathrm{r} /$ and $/ \curvearrowright /$, particularly after /p/ but also after other sounds. This metathesis has been active for a long time. Sherwood 1837's list of 'provincialisms' includes words like: perdigious, prevade, pervision and perserves. Hence, it is possible that in some cases dissimilation arose in the metathesized form of a word rather than in the standard form. For example, it might be that /sekəteri/ is derived from /sekərteri/ rather than /sekrəteri/. There is no way to be sure which words exist in the metathesized form (Hall,2009:4). Just like English, dissimilation in Arabic often manifests itself in metathesis.

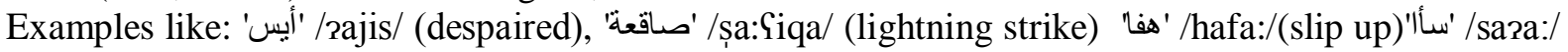
(worsened) 'شاكي' (barbed)/Ja:ki:/ are originated as the following words, respectively: 'ئس' /jazis/,

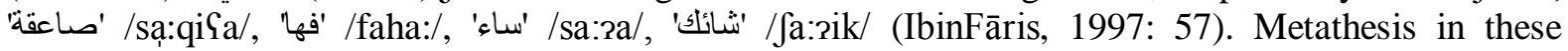


examples is provoked by dissimilation which is clearly apparent. However, there are instances like the word 'خطيئة' /xați:2a/(sin) which is when pluralized passes through different phases: 'خطيئة' /xați:a/ $\rightarrow$

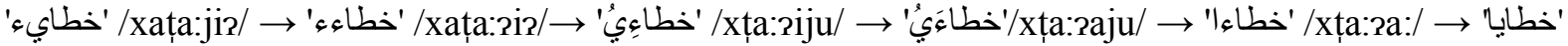
/xța:ja:/ (sins). These phases are all triggered via dissimilation which arises in the metathesized form of a word rather than in the original form (ibid).

Another specific case of dissimilation is dissimilatory loss, i.e., the complete elimination of a segment as it is the case of deleting $/ \mathrm{r} /$ and retaining the $/ \partial /$ in unstressed syllables. Examples may include $/ \partial+\mathrm{r} /$ that dissimilate to / $/ \mathrm{\partial}$ as in performance /porforməns/, perfumery /pərfjuməri/, or $/ \mathrm{r}+\mathrm{\partial} /$ dissimilating to /ə/ as in spectrogram /spektrogram/.Other examples can be found, especially in many varieties of American English, in which a dropping of one /r/ from certain words that contain two $/ \mathrm{r} / \mathrm{s}$ occurs within the process of dissimilation as in surprise, particular, governor, and corner. This type of $/ \mathrm{r} /$ deletion is done by speakers who are basically 'rhotic'; that is, who generally do not drop $/ \mathrm{r} /$ in any other position. It is considered as a type of dissimilation because it avoids the presence of multiple rhotics within a word (Hall, 2009:1). The opposite way also occurs to ensure dissimilation. However, it is adding (rather than deleting) /r/ sound. This may be due to resonances which may cause listeners to err on the side of perceiving too many $/ \mathrm{r} / \mathrm{s}$, and this produces colloquial insertion of $/ \mathrm{r} /$ in words already containing an / $\mathrm{r} /$, such as farmiliar, perservere, and sherbert (ibid:2)

On another vein, dissimilation can be achieved in Arabic through certain processes of Idhār /zið̄ha:r/ (showing) which is a special case of dissimilation with a specific treatment of the sound $/ \mathrm{n} /$. It is somehow opposite to the phenomenon of similitude found in English or that of 'ikhfā' /rixfa:2/ (hiding) found in Arabic Sībawayh (1975: 454). The whole process deals with the sound /n/ which has a special value in Arabic. In its ordinary behavior, $/ \mathrm{n} /$ is assimilated partially if followed by $/ \mathrm{m}, \mathrm{n}, \mathrm{w}, \mathrm{j}$, $\mathrm{b} /$, totally if followed by /r/ and /l/. If /n/ is followed by /t, d, k, s, z, f, $\theta, \partial, \mathrm{d} 3, \int, s$, , ḍ, ț, ọ, q/ a special case of assimilation occurs in which the sounds in concern affect each other by exchanging some features but remain relatively autonomous, e.g./rinkasara/ $\rightarrow /$ /rinkasara/ (it has been broken). The sounds $/ \mathrm{n}, \mathrm{k} /$ assimilate to one another to some extent: the allophone $[\tilde{\mathrm{k}}]$ is a subsidiary sound of the phoneme $/ \mathrm{k} /$ and is used when a nasal precedes it. However, this rule is violated by six consonants: $/ 2$, $\mathrm{h}, \mathrm{x}, \mathrm{C}, \mathrm{r}, \mathrm{h} /$. When $/ \mathrm{n} /$ is followed by one of these six sounds, it is not assimilated, rather it is dissimilated (ibid). Dissimilation occurs here in order to show that $/ \mathrm{n} /$ is not assimilated as expected and its nasalization is not affected either. $/ \mathrm{n} /$ is not assimilated here because of the distant places of articulation of the sounds in concern, e.g.' من حول' /min hawl/ (around), and 'من غير' /min rajr/ (without) where $/ \mathrm{n} /$ in both examples is having its pronunciation emphasized to show that $/ \mathrm{n} /$ dissimilates the following sound, $/ \mathrm{h} /$ and $/ \mathrm{r} /$ respectively (ibid).

\section{Comparative Analysis Findings}

On the basis of the theoretical survey concerning dissimilation process, it has been found that English and Arabic languages share almost the same incentives and causes for dissimilating sounds. However, the process seems more sporadic in English than its counterpart in Arabic. In Arabic, the dissimilation patterns are stronger for consonant pairs that are adjacent in the root than for consonant pairs that are non-adjacent in the root, hence locality principle is regarded as basic in triggering dissimilation process. Dissimilation is mainly applied in Arabic within the root domain while in English language it is within the syllable domain that this principle operates. Moreover, in Arabic language, the 'stretched out' features that have longer temporal intervals are more likely to dissimilate than others. These principles also apply to English but in a lesser effect.

As far as dissimilation classification in both languages, it has been found that the parameters that have been used to classify dissimilation are found somehow similar in both languages. Both languages exhibit examples in which the parameters of directionality, distance, influence as well as time are used to classify dissimilation process. The issues of the diachronic development of dissimilation in both languages seem more common than their synchronic types, though the latter is also found in both languages. Most dissimilatory examples within both languages prove to be sporadic and quantal. The sporadic character of dissimilations like the $\mathrm{r} / \mathrm{l}$ exchange goes back to older regularity, however, there is no positive evidence for it. Another proof for the irregularity evidence is the sporadic change of the Latin -alis/-aris to be added to the English roots. The quantal character can be derived from the phonemic change implied by the contrastiveness of the dissimilating features. 
Dissimilation is mainly achieved by dissimilating sounds, however, other processes are found to support this phenomenon. Processes like metathesis, deletion and addition are found as cases that exhibit dissimilation in English. Similarly, it is mainly within the processes of metathesis and idhār that dissimilation is achieved in Arabic language. Consequently, different ways are used to avoid similar sound structures, one, and the main, of which is the process of making them dissimilar.

\section{Conclusion}

The process of dissimilation can be best viewed as an optional, sporadic and quantal phonological process in English while it is more regular and systematic in Arabic in that in the latter language it can be expected and guessed according to word root, locality and lexicology. The process is mainly motivated by a number of factors. These factors could be as diverse as the interplay between production and perception as they relate to ease of articulation, historical developments, social attitudes and to the language community. The first factor refers to speech simplicity in that some dissimilatory variants are phonologically simpler and better. The second is the issue of language development and change while the last two factors favor one version over the other in that the choice to use and preserve dissimilation reflects the language users' preferences and choices, hence a sociolinguistic influence. In addition to these factors, the perceptual enhancement factor proves to be the most plausible one. This factor has been given such importance since within dissimilation process, differences between sounds are enhanced so that sounds become more auditorily distinct and this, in turn, makes speech perception easier. Dissimilation has been interpreted as enhancing perceptibility while demanding more complex articulations than in sequences of non-dissimilated segments so that it facilitates the task of the listener. The goal of dissimilation, then, is to enhance a contrast by improving the auditory distance between the target and the trigger and thus facilitates perception.

\section{REFERENCES}

Abduttawāb, R. (1989) At-Tațawwur Al -Lughawī: Madhāhiruhuwa' Ilaluhuwaqaw ānīnuhu (Linguistic Development: its Shapes, Reasons, and Laws). $1^{\text {st }}$.ed. Al-Khānjī Library, Cairo.

Abdul-Jalīl, A. (2014) Al-Așwāt Al -Lughawiyyah (The Linguistic Sounds). $2^{\text {nd }}$ ed. DārȘafā' for Printing, Publication, and Distribution, Ammān.

Anīs, I. (1995) Al-Așwāt Al-Lughawiyyah (The Linguistic Sounds). The Anglo-Egyptian Library, Cairo.

Berg, Th. (1998) Linguistic Structure and Change: An Explanation from Language Processing. Oxford: Clarendon Press.

Baḥra, S. (2010) "Qānūn Al-Mukhālafa Aș -Șawtiyyah wa Atharuhu fī NumuwAth-Tharwah AlLafdiyya Lil -Arabiyyah Al-Fushā" (Dissimilation and its Effect in the Growth of Arabic Vocabulary) in: Tishreen University Journal for Research and Scientific Studies-Art and Humanities Series. vol. 32, no. 3.Pp: 27-46.

Bergstrasser, G. (1994) At-TatawwurAn-Nahawī Lil -Lughah Al-Arabiyyah (The Grammatical Development of the Arabic Language). $2^{\text {nd }}$ ed. Trans.R. Abdut-Tawwāb. Al-Khānjī Library, Cairo.

Brokelman, C. (1977) FiqhAl-LughātAs-Sämiyah (The Philology of Semitic Languages). Trans. Ramadḍān Abdut-Tawwāb. Ar-Riyāḍ University, KSA.

Campbell, L. (2004). Historical Linguistics: An Introduction (2 ${ }^{\text {nd }}$ ed). Cambridge: MIT Press.

Collier, C.A. (2013) "Liquid Dissimilation as Listener Hypercorrection". In Proceedings of the 37th Annual Meeting of the Berkeley Linguistics Society, pp. 3-17.

Crystal, D. (2008) A Dictionary of Linguistics and Phonetics (6 ${ }^{\text {th }}$ ed). Oxford: Blackwell Publishers.

Denham, K. and Lobeck, A. (2010) Linguistics for Everyone: An Introduction. Boston: Wadsworth Publishing Company.

Donegan, P. (2001) "Normal Vowel Development" . In www.ling.hawaii.edu/ faculty /donegan/.../201Xvoweldevel.pdf. Retrieved on March/2016.

Fletch, H. (1983) Al-Arabiyyah Al-Fușha Naḩw aBinā' Lughawì Jadīd (Standard Arabic: Toward a Modern Linguistic Structure). Trans. A. Shāhīn. $2^{\text {nd }}$ ed. Dār Al-Mashriq, Beirut.

Frisch, S. (2004)"Language Processing and OCP Effects". In B. Hayes,R. Kirchner \& D. Steriade (eds.), Phonetically-based Phonology. Cambridge: Cambridge University Press, pp. 346-371. 
Hall, N.(2009) "Long-Distance /r/-Dissimilation in American English". In www. csulb.edu/ nhall2/dissimilation_ paper. pdf. Retrived on February/2016.

Hickey, R. (1984) "Remarks on Assimilation in Old English" in Folia Linguistica Historica. Vol 5, Issue 2, pp. 279-303.

Ibin Fāris, A. (1997) Aș-Șāhibì fíFiqh Al -Lugha Al-Arabiyya (Aș-Șāhibīin Arabic Philology ). Ed. A.Bisij. Dar Al-Kutub Al-Ilmiyyah, Beirut.

Ibin Jinnī , U. (2010) Al-Khașā'ș (The Properties). Ed. M.An-Najjār. $4^{\text {the }}$ ed. Egyptian General Book Authority, Cairo.

Ibin Mandhūr, J. (1988) Lisān Al-Arab (The Arab's Tongue (Language)).Ed. A. Sheri. $1^{\text {st }}$ ed.Dār 'Ihyāa' At-Turāth Al-'Arabī, Beirut.

Jeffries, L. (2006) Discovering Language: the Structure of Modern English. London: Macmillan.

Al-Kisā'̄', A. (1982) MāTulhinubihil'Āmmah (What the Public Mispronounce). Ed. R .Abduttawwāb. $1^{\text {st }}$ ed. Al-Khānjī Library, Cairo.

Lawrence, J. (1973) "Dissimilation as a Natural Process in Phonology". In files.eric.ed.gov/fulltext/ED081281.pdf. Retrieved on February/ 2016.

Malamberg, B. (1984) 'IlmAl-Așwāt (Phonetics). Trans. A. Shāhīn. Ash-Shabāb Library, Cairo, Egypt.

Ohala, J. (1981) "The listener as a source of sound change". In Chicago Linguistic Society: Papers from the Parasession on Language and Behavior. Chicago: CLS, pp. 178-203.

(1992) "Alternatives to the Sonority Hierarchy for Explaining Segmental Sequential Constraints". In Chicago Linguistic Society:Papers from the Parasession on the Syllable. Chicago: CLS, pp. 319-38.

(1993) "The Phonetics of Sound Change". In C. Jones (ed.), Historical Linguistics: Problems and Perspectives. London: Longman, pp. 237-78.

Ar-Rāzī, I. (1993) Fiqh Al-Lugha Al-Arabiyyah (The Philology of the Arabic Language). Ed. O. AțTabbā'. $1^{\text {st }}$ ed. Al-Ma'ārif Library, Beirut, Lebanon.

Sībawayh, A. (1975)Al-Kitāb (The Book ). Ed. Muhammad Abdussalām Hārūn. Al-Khānjī Library, Cairo.

Strazny, P. (2005) Encyclopedia of linguistics. New York: Taylor and Francis Books.

Zedān, J. (1982) Al-Falsafa Al-LughawiyyawalAlfādh Al-'Arabiyya (Linguistic Philosophy and Arabic Vocabulary). Ed. M. Kāmil. $2^{\text {nd }}$ ed. DārAl-Hadātha, Beirut.

Yip, M. (1995) "Repetition and its Avoidance: The Case of Javanese". Appeared in K. Suzuki and D. Elzinga, (eds.), Proceedings of Southwest Optimality Workshop I: Features in Optimality Theory. Coyote Working Papers, University of Arizona,Tucson.

\section{Appendix}

\section{Key to Arabic Symbols:}

\section{Consonants}

\begin{tabular}{|c|c|c|c|}
\hline Arabic Symbol & Transliteration & Phonetic Transcription & Phonetic Values \\
\hline$s$ & , & $?$ & voiceless glottal stop \\
\hline . & $\mathrm{h}$ & $\mathrm{h}$ & voiceless glottal fricative \\
\hline$\tau$ & $\mathrm{h}$ & $\mathrm{h}$ & voiceless pharyngeal fricative \\
\hline$\varepsilon$ & & ؟ & voiced pharyngeal fricative \\
\hline$\dot{\tau}$ & $\mathrm{kh}$ & $\mathrm{x}$ & voiceless uvular fricative \\
\hline$\dot{\varepsilon}$ & $\overline{\mathrm{gh}}$ & $\gamma$ & voiced uvular fricative \\
\hline ق & $\mathrm{q}$ & $\mathrm{q}$ & voiced uvular stop \\
\hline 5 & $\mathrm{k}$ & $\mathrm{k}$ & voiceless velar stop \\
\hline ج & $\mathrm{J}$ & d3 & voiced palatal stop \\
\hline ي & $\mathrm{y}$ & $\mathrm{J}$ & voiced alveo-palatal semi-vowel \\
\hline ش ش & $\underline{\mathrm{sh}}$ & $\int$ & voiceless alveo-palatal fricative \\
\hline د & $\mathrm{d}$ & $\mathrm{d}$ & voiced alveolar stop \\
\hline$ت$ & $\mathrm{t}$ & $\mathrm{t}$ & voiceless alveolar stop \\
\hline$b$ & ț & $\mathrm{t}$ & voiced emphatic alveolar stop \\
\hline J & 1 & 1 & voiced alveolar lateral \\
\hline
\end{tabular}


The Process of Dissimilation in English and Arabic: A Comparative Study

\begin{tabular}{|c|c|c|c|}
\hline J & $\mathrm{r}$ & $\mathrm{r}$ & voiced alveolar trill \\
\hline ض & 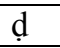 & $\underline{\mathrm{d}}$ & voiced emphatic alveolar fricative \\
\hline ن & $\mathrm{n}$ & $\mathrm{n}$ & voiced alveolar nasal \\
\hline ص ص & $\underline{s}$ & $\underline{s}$ & voiceless emphatic alveolar fricative \\
\hline j & $\mathrm{z}$ & $\mathrm{Z}$ & voiced alveolar fricative \\
\hline س & $\mathrm{s}$ & $\mathrm{s}$ & voiceless alveolar fricative \\
\hline ظ & $\mathrm{dh}$ & $\underline{\partial}$ & voiced emphatic interdental fricative \\
\hline$\dot{j}$ & $\underline{\text { th }}$ & $\dot{\partial}$ & voiced interdental fricative \\
\hline$\dot{H}$ & $\underline{\text { th }}$ & $\theta$ & voiceless interdental fricative \\
\hline ف & $\mathrm{f}$ & $\mathrm{f}$ & voiceless labiodental fricative \\
\hline ب & $\mathrm{b}$ & $\mathrm{b}$ & voiced bilabial stop \\
\hline 5 & $\mathrm{~m}$ & $\mathrm{~m}$ & voiced bilabial nasal \\
\hline 9 & $\mathrm{~W}$ & $\mathrm{~W}$ & voiced bilabial semi- vowel \\
\hline
\end{tabular}

2. Vowels

\begin{tabular}{|c|c|c|c|}
\hline Arabic Symbol & Transliteration & Phonetic Transcription & Phonetic Values \\
\hline 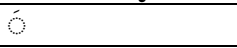 & $\mathrm{a}$ & $\mathrm{a}$ & Mid-open, mid-central, unrounded \\
\hline ? & $\mathrm{u}$ & $\mathrm{u}$ & Mid-close, back, slightly rounded \\
\hline ? & $\mathrm{i}$ & $\mathrm{i}$ & Mid-close, front, unrounded \\
\hline 1 & $\overline{\mathrm{a}}$ & $\mathrm{a}:$ & Open, front, unrounded \\
\hline 9 & $\overline{\mathrm{u}}$ & $\mathrm{u}:$ & Close, back, rounded \\
\hline ي & $\overline{1}$ & i: & Close, front, spread \\
\hline
\end{tabular}

\section{AUTHORS' BIOGRAPHY}

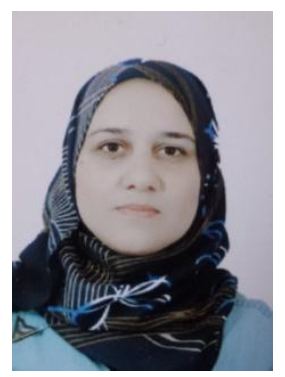

Dr. Aseel Muhammad Faiq, Ph.D. in English Language and Linguistics. From 2001 to 2006, she has been teaching in the University of Baghdad. In 2007 she came to Kurdistan Region of Iraq teaching in the college of Education then college of Languages and became one of the latter's staff members since 2009. Her major field of interest in linguistics is Discourse Analysis, Pragmatics and Phonology.

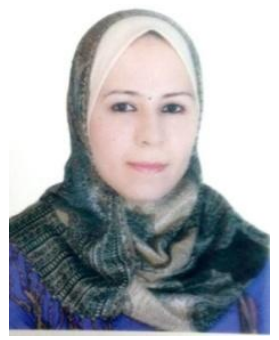

Dr. Israa Burhanuddin, Ph.D. in English Language and Linguistics. From 1996 to 2007, she has been teaching in Tikrit Developed Secondary School for Girls. In 2007 she began to teach in the English Department at the College of Education for Women at Tikrit University. Her major field of interest in linguistics is Phonetics and Phonology, Pragmatics and Stylistics. 